\title{
Prognostic Value of CD45 Surface Antigen in Children with Acute Lymphoblastic Leukemia Treated according to Total XV Protocol
}

\author{
SHEBL S. SHEBL, M.D.*; MOHAMED A. SAAD, M.D.**; IBRAHIM M. BADRAIA, M.D.* and \\ AMIRA M. ABO ELELA, M.Sc.* \\ The Departments of Pediatric Hematology \& Oncology* and Clinical Pathology**, Faculty of Medicine, \\ Tanta University, Egypt
}

\begin{abstract}
Background: Acute Lymphoblastic Leukemia (ALL) is a malignant disease of the bone marrow in which early lymphoid precursors proliferate and replace the normal hematopoietic cells of the marrow. Further improvement of outcome in childhood acute lymphoblastic leukemia could be achieved by identifying additional high-risk patients who may benefit from intensified treatment. CD45 cell surface antigen is a transmembrane protein with tyrosine phosphatase activity, expressed by all nucleated cells of hematopoietic origin, except erythrocytes and platelets.
\end{abstract}

Aim of Study: To assess the prognostic value of CD45 surface antigen in children with acute lymphoblastic leukemia who treated according to TOTAL XV protocol.

Subjects and Methods: This study was conducted on 25 patients with acute lymphoblastic leukemia who treated according to Total XV protocol. CD45 expression was measured by flowcytometry and cut-off value for CD45 expression is set on $90 \%$ to distinguish a CD45-high from a CD45-low group.

Results: There was significant correlation between CD45 expression and age. There was no statistically significant differences between low and high CD45 groups as regard initial total leucocytic count, bone marrow blast cells percentage, leukemic phenotype, DNA index, $t(9,22)$ or CNS status. There was statistically significant difference between the two groups regarding early treatment response, risk stratification, incidence of relapse and event free survival.

Conclusion: Measuring the intensity of expression of CD45 surface antigen has a prognostic value in childhood acute lymphoblastic leukemia. So consideration of CD45 expression may serve as an additional stratification tool.

Recommendations: Multicenter study on large number of patients with follow-up for longer duration is recommended to prove the prognostic value of CD45 expression in childhood acute lymphoblastic leukemia.

Key Words: Acute lymphoblastic leukemia - CD45 surface antigen - Total XV protocol.

Correspondence to: Dr. Shebl S. Shebl, The Department of Pediatric Hematology \& Oncology, Faculty of Medicine, Tanta University, Egypt

\section{Introduction}

ACUTE Lymphoblastic Leukemia (ALL): ALL is a malignant clonal disorder of bone marrow lymphopoietic precursor cells with progressive medullary and extramedullary accumulation of lymphoblast that decreases the potential for differentiation and maturation [1].

ALL is the most common childhood malignancy, constituting about one third of childhood cancer [2]

With improvements in diagnosis and treatment, overall cure rates for children with ALL have reached $90 \%$. The use of risk-adapted treatment protocols has improved cure rates while limiting the toxicity of therapy [3].

Although treatment of acute lymphoblastic leukemia has improved continuously over the last decades, first-line therapy still fails in approximately $20 \%$ of cases and children suffer from disease recurrence [4].

Further reduction of relapse in childhood ALL could be achieved by identifying additional highrisk patient who may benefit from treatment intensification [5]

\section{CD45 Antigen:}

The leukocyte common antigen or CD45 is found on all hematopoietic cells except erythrocytes and platelets and is absent from non hematopoietic tissues. It belongs to a family of cell surface glycoproteins with a heavily glycosylated extracellular domain, a transmembrane segment, and a large cytoplasmic domain that contains tyrosine phosphatase activity [6] 
Since CD45 is exclusively found on hematopoietic cells, apart from erythrocytes and platelets, its greatest diagnostic value is in distinguishing the hematopoietic from the nonhematopoietic tissue [7].

CD45 is a part of the immunophenotyping marker panels for the diagnosis of acute leukemias. It is used to define the blast population, on which the expression of differentiation antigens is to be focused [8]

Routinely, CD45 expression was reported in terms of percentage of positive cells. This approach does not, however, allow for quantification of the brightness of expression. In fact, using this approach we were previously unable to demonstrate an association between CD45 expression and prognosis because blast cells are generally CD45 positive and the number of true negative CD45 cases in ALL is very rare, or may not exist at all [9].

By contrast, analysis of CD45 antigen by demonstration of its density on blast cells revealed its potential prognostic significance [5]

\section{Patients and Methods}

This study was done after approval from Ethical Committee of Research Center of Tanta University Hospital and written consent from parents of included children in this research and was carried out at Hematology and Oncology Unit, Pediatric Department, Tanta University between April-2017 and April 2018 on 25 patient of acute lymphoblastic leukaemia-including precursor B-cell and T-cell phenotype-who received risk-oriented therapy depend on the stratification criteria which divide them into low risk, standard risk, and high risk patients according to total XV protocol.

Patient's age ranged from 2-7 years, with mean \pm SD $6.88 \pm 4.62$. They were 17 males $(68 \%)$ and 8 females (32\%).

All patients was subjected to detailed history, thorough clinical examination, radiological investigation-including abdominopelvic U/S, chest Xray, echocardiography and testicular U/S in malesand laboratory investigations include the following: CBC, ESR, LDH, liver and renal function test, Serum uric acid, $\mathrm{Na}, \mathrm{K}, \mathrm{Ca}$, $\mathrm{Ph}$ serum level, coagulation profil, lumber puncture for CSF examination and bone marrow aspiration and examination by the following: (Leishman stained smears to detect the percentage of blast cells, cytochemical analysis, Immunopheno-typing of blast cells by flowcytometry, cytogenetic study including DNA index and $t(9,22)$ and MRD assessment at day 15 and at end of induction therapy).

Diagnosis of acute lymphoblastic leukemia was based on morphological, cytochemical and immunophenotypic characteristics of leukemic blasts.

Flow cytometric measurement and quantification of CD45 surface expression:

CD45 expression was routinely assessed at diagnostic immunophenotyping, samples were taken prior to the initiation of treatment, they were analyzed and reported according to the guidelines proposed by the European Group for the Immunological Characterization of Leukemias (EGIL). Accordingly, antigen expression was quantified in terms of percentage of positive cells as compared to an antigen-negative subpopulation.

In the study presented here, we re-analyzed the "raw" flow cytometric data and quantified CD45 expression in order to provide a full-scale estimation of CD45 expression. To control for technical variation, we normalized the measured expression values by use of normal mature B-and T-lymphocytes within the same sample, which are known to express high levels of CD45 stably. The resulting expression values are described as relative ratios of mean fluorescence intensity of CD45 in leukemic versus normal cells in percentages.

The cutoff point was set on $\geq 90 \%$ to distinguish CD45-low from CD45-high groups.

All patients were treated according to total XV protocol which consists of remission induction, consolidation and continuation phases [10].

Remission induction: Consists of prednisone $40 \mathrm{mg} / \mathrm{M}^{2} / \mathrm{d}(\mathrm{d} 1-\mathrm{d} 28)$, vincristine $1.5 \mathrm{mg} / \mathrm{m}^{2}$ (d1, $8,15,22)$, Doxorubicin $25 \mathrm{mg} / \mathrm{m}^{2}(\mathrm{~d} 1,8), 1-$ asparginase $10000 \mathrm{U} / \mathrm{m}^{2}(\mathrm{~d} 2,4,6,9,11,13)$, cyclophosphamide $1000 \mathrm{mg} / \mathrm{m}^{2}(\mathrm{~d} 22)$, cytarabine $75 \mathrm{mg} / \mathrm{m}^{2}$ (d23-d26 and d30-d33), Mercaptopurine $60 \mathrm{mg} / \mathrm{m}^{2} /$ day $(\mathrm{d} 22-\mathrm{d} 35)$, triple intrathecal $(\mathrm{d} 1,15)$. Upon hematopoietic recovery (between day 39 and 42), MRD was assessed and consolidation therapy began.

Patients were followed-up to assess their response to treatment and for incidence of relapse.

Definition of complete remission and relapse: Complete Remission (CR) is defined as a cellularity of more than $20 \%$ with fewer than $5 \%$ blasts in bone marrow after induction chemotherapy. 19 relapse is defined by the appearance of one of the following: (1) More than 50\% lymphoblasts in a 
single BM aspirate; (2) More than 25\% lymphoblasts in BM and $2 \%$ or more circulating lymphoblasts; (3) Progressive repopulation of lymphoblasts in excess of $5 \%$ culminating in more than $25 \%$ on two or more BM samples separated by 1 week or more; (4) Leukemic cell infiltration in extra medullary organs as gonads; (5) Lymphoblasts in CSF with cell count greater than $5 \mathrm{WBCs} / \mathrm{mm}^{3}[11]$
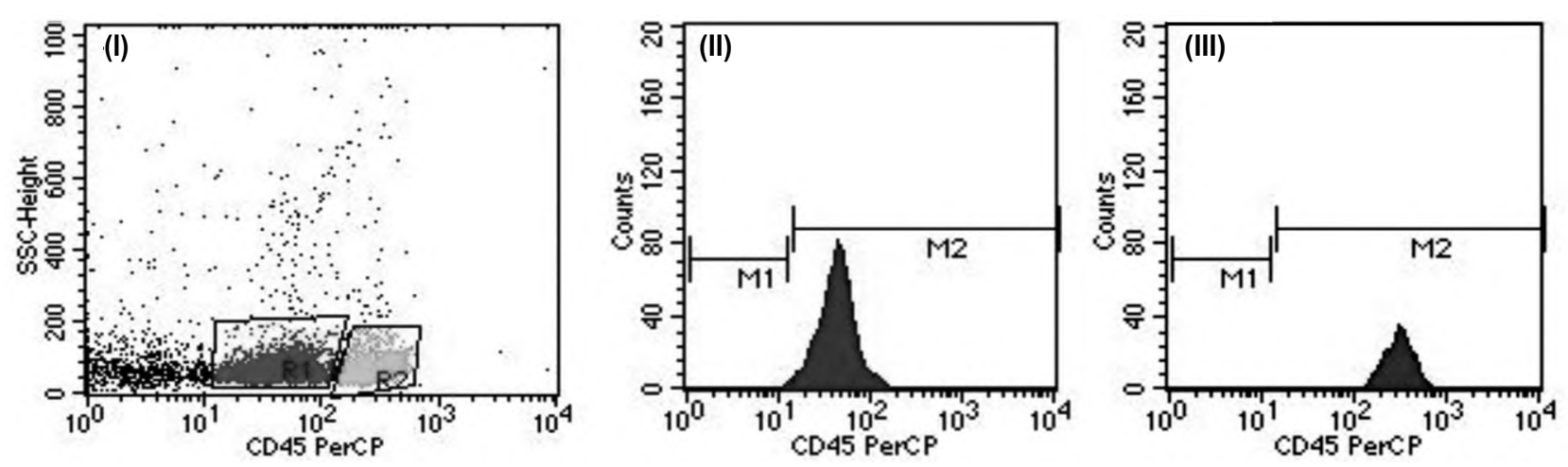

Fig. (1): Flow cytometric analysis of a case with low CD45 expression.

I : Lymphobl ast (red) and lymphocyte (green) in a CD45/SSc dot plot.

II : MFI of CD45 on lymphobl ast.

III : MFI of CD45 on lymphocyte.

\section{Statistical analysis:}

Statistical presentation and analysis of the present study was conducted, using the mean, standard deviation and chi-square test by SPSS V. 22. Mean value, Standard Deviation [SD], Standard student " $t$ test", Chi-square test and Linear Correlation Coefficient $[r]$.

\section{Results}

In (Table 1): There is statistical significant difference between age groups and CD45 expression. In low CD45 expression group, age of patient range from 2-8 years (favorable age group) years with mean \pm SD $(4.25 \pm 2.04)$. In high CD45 expression group, age of patient ranges from 3-17 years with mean $\pm \mathrm{SD}(8.63 \pm 5.07)$.

No statically significance between WBCs count groups at initial diagnosis and CD45 expression (Table 2).

Table (1): Relationship between CD45 expression and age groups.

\begin{tabular}{|c|c|c|c|c|c|}
\hline \multirow[b]{2}{*}{ Age } & \multicolumn{3}{|c|}{$\mathrm{CD} 45$} & \multirow[b]{2}{*}{$\chi^{2}$} & \multirow{2}{*}{$\begin{array}{c}p- \\
\text { value }\end{array}$} \\
\hline & $\begin{array}{c}\text { Total } \\
(\mathrm{N}=25)\end{array}$ & $\begin{array}{c}\text { Low } \\
(\mathrm{N}=10)\end{array}$ & $\begin{array}{l}\text { High } \\
(\mathrm{N}=15)\end{array}$ & & \\
\hline \multicolumn{6}{|c|}{$<10$} \\
\hline $\mathrm{N}$ & 19 & 10 & 9 & 5.263 & $0.022 *$ \\
\hline$\%$ & $76 \%$ & $100.0 \%$ & $60.0 \%$ & & \\
\hline \multicolumn{6}{|l|}{$\geq 10$} \\
\hline $\mathrm{N}$ & 6 & 0 & 6 & & \\
\hline$\%$ & $24 \%$ & $.0 \%$ & $40.0 \%$ & & \\
\hline
\end{tabular}

Table (2): Relationship between CD45 expression and WBCs count groups.

\begin{tabular}{llllll}
\hline $\begin{array}{l}\text { WBÇs count } \\
\left(* 10 / \mathrm{mm}^{3}\right)\end{array}$ & $\begin{array}{c}\text { Total } \\
(\mathrm{N}=25)\end{array}$ & $\begin{array}{c}\text { Low } \\
(\mathrm{N}=10)\end{array}$ & $\begin{array}{c}\text { High } \\
(\mathrm{N}=15)\end{array}$ & $\chi^{2}$ & $\begin{array}{c}p- \\
\text { value }\end{array}$ \\
\cline { 2 - 4 } & & & & & \\
\hline$<50:$ & 20 & 8 & 12 & 0.0 & \\
$\mathrm{~N}$ & $80.0 \%$ & $80.0 \%$ & $80.0 \%$ & & 1.0 \\
$\%$ & & & & & \\
$\geq 50:$ & 5 & 2 & 3 & & \\
$\mathrm{~N}$ & $20.0 \%$ & $20.0 \%$ & $20.0 \%$ & \\
$\%$ & & & & \\
\hline
\end{tabular}

Table (3): In low CD45 expression group, $60 \%$ of patients were of pre B phenotype, $20 \%$ common $\mathrm{B}, 10 \%$ early pre B and $10 \%$ intermediate $\mathrm{T}$. In high CD45 expression group, $40 \%$ of patients were of pre B phenotype, $26.7 \%$ early pre B, $13.3 \%$ early $\mathrm{T}, 13.3 \%$ intermediate $\mathrm{T}$ and $6.7 \%$ common $\mathrm{B}$, with no statistical significance.

No statistical significance was found between CD45 expression and DNA index (Table 4).

In (Table 5) $100 \%$ and $93.3 \%$ of patients with low CD45 and high CD45 expression respectively were -ve for BCR/ABL fusion gene. $6.7 \%$ of patient with high CD45 were +ve for BCR/ABL fusion gene, with no statistical significance. In (Table 6): At end of induction MRD was not detected $(<0.01 \%)$ in $90 \%$ and $60 \%$ of patients in low CD45 and high CD45 groups respectively MRD was positive $(\geq 0.01 \%)$ in $10 \%$ and $40 \%$ of 
patients in low and high CD45 groups respectively, with no statistical significance.

Table (3): Association between CD45 expression and leukemic phenotype.

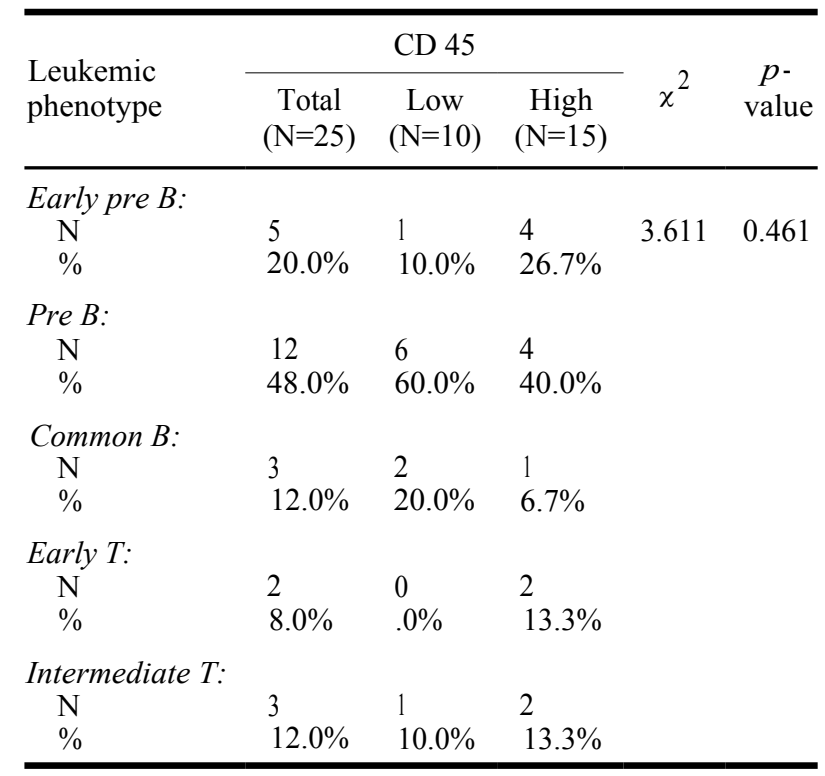

Table (4): Comparison between DNA index in low and high CD45 expression groups.

\begin{tabular}{lllll}
\hline CD 45 & Range & Mean \pm S.D & $t$-test & $p$-value \\
\hline DNA index: & & & & \\
$\quad$ Low & $1-1.32$ & $1.05 \pm 0.11$ & 2.896 & 0.102 \\
High & $1-1$ & $1.00 \pm 0.00$ & & \\
\hline Total & $1-1.32$ & $1.02 \pm 0.07$ & & \\
\hline
\end{tabular}

Table (5): Relationship between presences of BCR/ABL fusion gene and CD45 expression.

\begin{tabular}{llllll}
\hline $\begin{array}{l}\text { BCR/ABL } \\
\text { fusion } \\
\text { gene }[t(9,22)]\end{array}$ & $\begin{array}{c}\text { Total } \\
(\mathrm{N}=25)\end{array}$ & $\begin{array}{c}\text { Low } \\
(\mathrm{N}=10)\end{array}$ & $\begin{array}{c}\text { High } \\
(\mathrm{N}=15)\end{array}$ & & $\begin{array}{c}\chi^{2} \\
\text { value }\end{array}$ \\
\cline { 2 - 4 } & & & & & \\
\hline $\begin{array}{l}\text { Positive: } \\
\mathrm{N} \\
\%\end{array}$ & 1 & 0 & 1 & 0.694 & 0.405 \\
& $4.0 \%$ & $.0 \%$ & $6.7 \%$ & & \\
$\begin{array}{l}\text { Negative: } \\
\mathrm{N}\end{array}$ & 24 & 10 & 14 & & \\
$\%$ & $96.0 \%$ & $100.0 \%$ & $93.3 \%$ & & \\
\hline
\end{tabular}

Table (6): Relationship between CD45 expression and Minimal Residual Disease (MRD) at end of induction.

\begin{tabular}{|c|c|c|c|c|c|}
\hline \multirow{2}{*}{$\begin{array}{l}\text { MRD at } \\
\text { end of } \\
\text { induction }\end{array}$} & \multicolumn{3}{|c|}{ CD 45} & \multirow{2}{*}{$x^{2}$} & \multirow{2}{*}{$\begin{array}{c}p- \\
\text { value }\end{array}$} \\
\hline & $\begin{array}{c}\text { Total } \\
(\mathrm{N}=25)\end{array}$ & $\begin{array}{c}\text { Low } \\
(\mathrm{N}=10)\end{array}$ & $\begin{array}{l}\text { High } \\
(\mathrm{N}=15)\end{array}$ & & \\
\hline \multicolumn{6}{|l|}{$<0.01 \%$ : } \\
\hline $\mathrm{N}$ & 18 & 9 & 9 & 2.679 & 0.102 \\
\hline$\%$ & $72.0 \%$ & $90.0 \%$ & $60.0 \%$ & & \\
\hline \multicolumn{6}{|l|}{$\geq 0.01 \%$ : } \\
\hline $\mathrm{N}$ & 7 & 1 & 6 & & \\
\hline$\%$ & $28.0 \%$ & $10.0 \%$ & $40.0 \%$ & & \\
\hline
\end{tabular}

In Fig. (2): $100 \%$ of patients with low CD45 expression could achieve Complete Remission (CR) early while only $66.7 \%$ of patients in the high group could do. With statistical significance, $p$-value $=0.041$ Fig. (2).

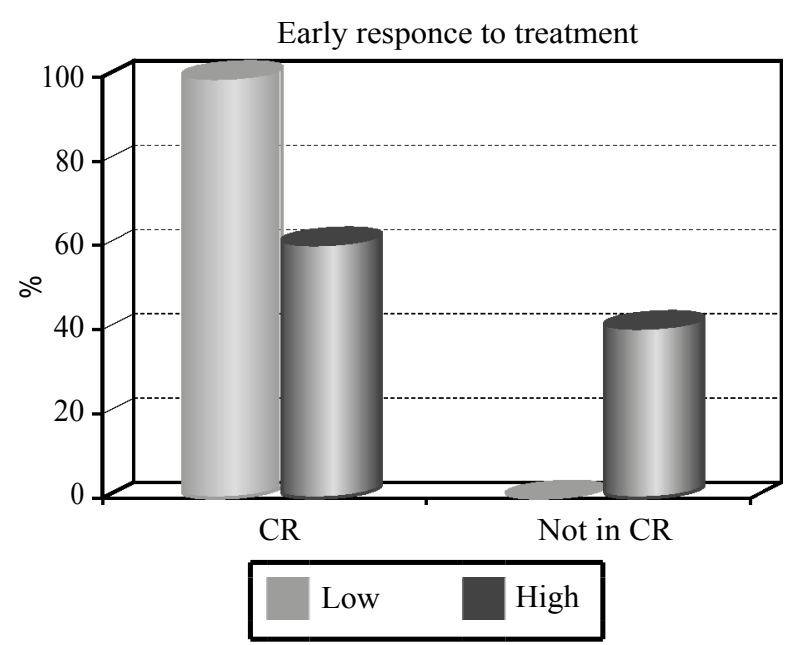

Fig. (2): Comparison between early treatment response in low and high CD45 expression groups.

In Fig. (3): In CD45-low group 80\% of patients were of Low Risk (LR) and 20\% were Standard Risk (SR). In CD45- high group $66.7 \%$ of patients were standard risk, $20 \%$ low risk and $13.3 \%$ high risk. With statistical significance ( $p$-value $=0.011)$.

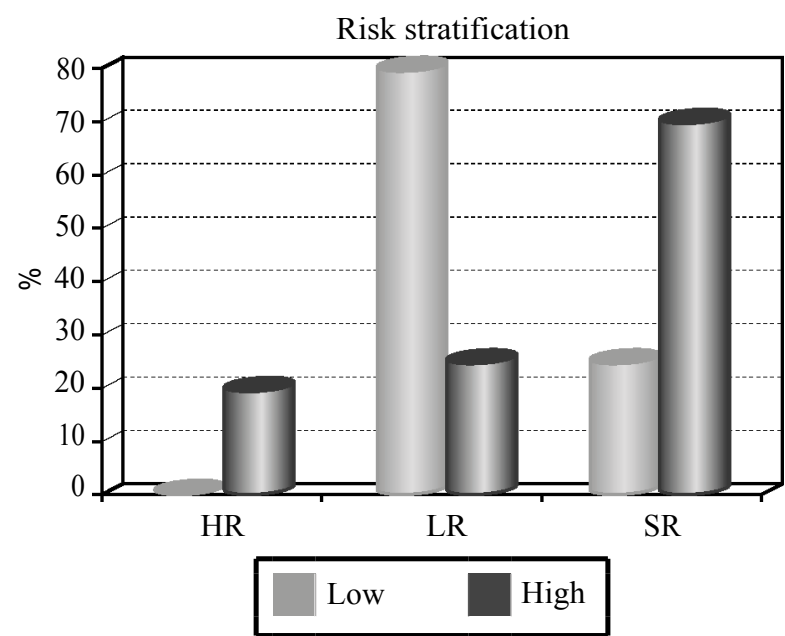

Fig. (3): Association between risk stratification and CD45 expression.

No relapse occurs in the low group while $46.7 \%$ of high group developed relapse, with statistical significance ( $p$-value $=0.011)$ Fig. (4).

2 year EFS was $80 \%$ in low CD45 expression versus $66.7 \%$ in high CD45 expression Fig. (5).

There was a highly significant positive correlation between age of patients and also no. of deaths with CD45 expression Figs. $(6,7)$. 


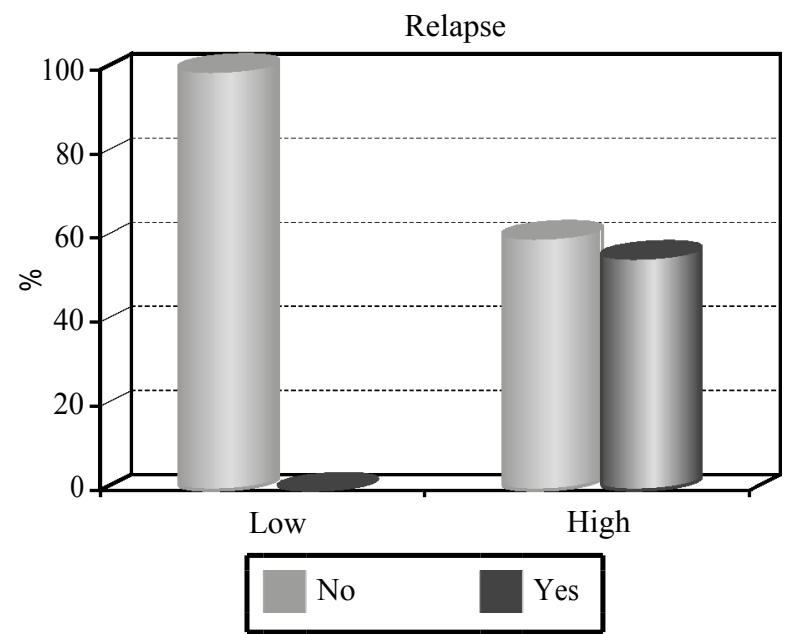

Fig. (4): Relationship between CD45 expression and occurrence of relapse.

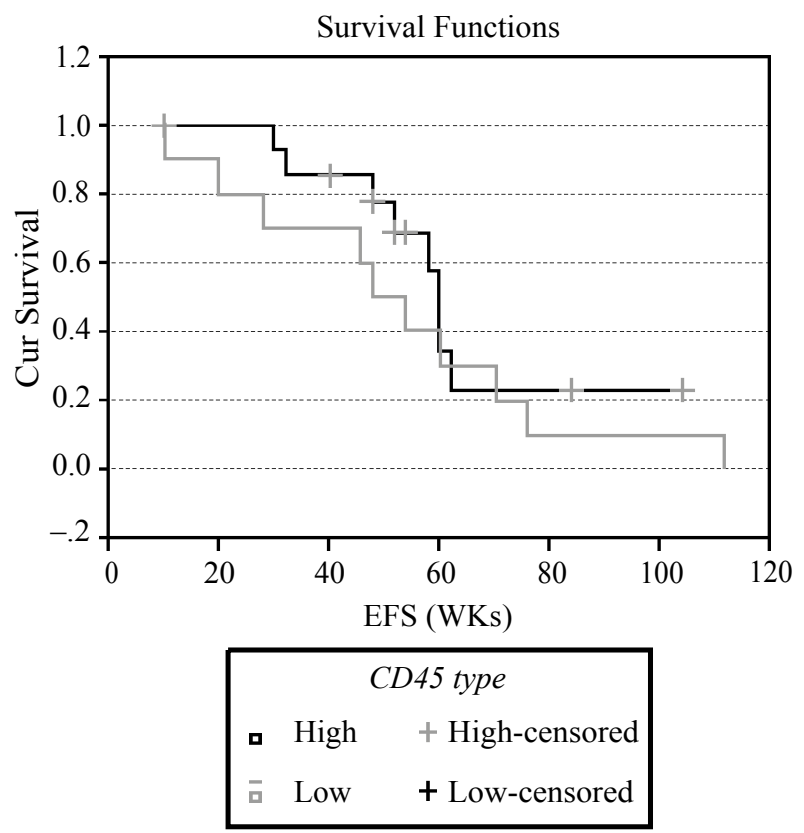

Fig. (5): Kaplan-Meier estimate of EFS for all patients.

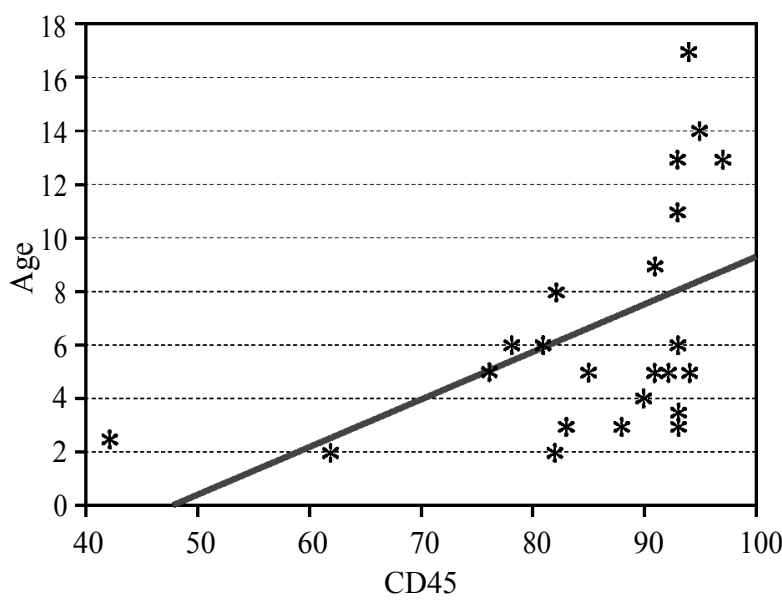

Fig. (6): Correlation between age and CD45 expression.

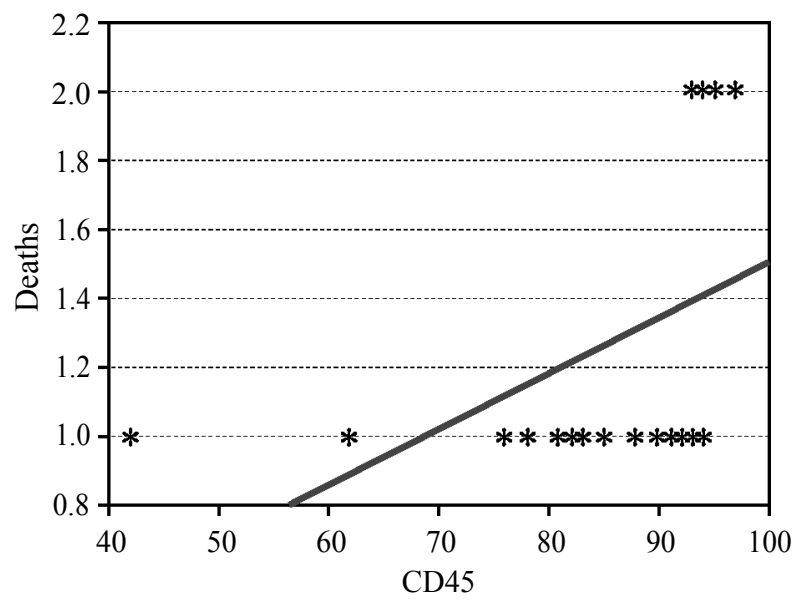

Fig. (7): Correlation between death rate and CD45 expression.

In multivariate analysis considering CD45 expression, age at diagnosis, WBCs count, CNS status, leukemic phenotype, DNA index, presence of BCR/ABL fusion gene and MRD at end of induction, CD45 represent statistically significant risk factor for risk stratification (Hazard ratio: 0.756 , confidence interval: $0.137-0.94, p$-value: 0.038 ) and for risk of death (Hazard ratio: 0.458, confidence interval: $0.176-0.857, p$-value: 0.032 ). (Tables 7,8).

Table (7): Cox regression analysis (risk stratification).

\begin{tabular}{lccc}
\hline \multirow{2}{*}{ Risk stratification } & \multicolumn{3}{c}{ Multivariate } \\
\cline { 2 - 4 } & $\mathrm{HR}$ & $(95 \% \mathrm{CI})$ & $p$-value \\
\hline - CD45 & 0.756 & $(0.137-0.947)$ & $0.038^{*}$ \\
- Age & 0.627 & $(0.254-0.879)$ & $0.021^{*}$ \\
- WBCs & 0.697 & $(0.317-2.853)$ & 0.108 \\
- CNS status & 0.857 & $(0.472-2.209)$ & 0.350 \\
- Leukaemic phenotyoe & 1.009 & $(0.986-1.032)$ & 0.457 \\
- DNA index & 0.517 & $(0.361-2.441)$ & 0.311 \\
- BCR/ABL fusion gene & 1.327 & $(0.746-5.858)$ & 0.627 \\
- $\left.t^{9}\left({ }^{9}, 22\right)\right]$ & & & \\
\hline
\end{tabular}

Table (8): Cox regression analysis (death).

\begin{tabular}{|c|c|c|c|}
\hline \multirow{2}{*}{ Death } & \multicolumn{3}{|c|}{ Multivariate } \\
\hline & HR & $(95 \% \mathrm{CI})$ & $p$-value \\
\hline - CD45 & 0.458 & $(0.176-0.857)$ & $0.032 *$ \\
\hline • Age & 0.448 & $(0.247-0.859)$ & $0.017^{*}$ \\
\hline - WBCs & 0.458 & $(0.108-5.137)$ & 0.385 \\
\hline - CNS status & 0.841 & $(0.458-1.932)$ & 0.512 \\
\hline - Leukaemic phenotyoe & 0.741 & $(0.369-2.541)$ & 0.584 \\
\hline - DNA index & 0.207 & $(0.119-2.508)$ & 0.459 \\
\hline $\begin{array}{l}\text { - } \mathrm{BCR} / \mathrm{ABL} \text { fusion gene } \\
\left.\left[t t^{9},{ }^{22}\right)\right]\end{array}$ & 1.526 & $(0.589-3.529)$ & 0.691 \\
\hline - MRD at end of induction & 0.875 & $(0.416-5.842)$ & 0.458 \\
\hline
\end{tabular}




\section{Discussion}

Regarding the relation between age and CD45 expression, $100 \%$ of patients of CD45-low group were in the favorable age group versus $60 \%$ of patients of CD45-high group. This agrees with [5] who found that among the low CD45 patient 56\% had a favorable age versus 17\% in the high CD45 group. But $[\mathbf{9 , 1 2 - 1 4}]$ failed to find any relation between age and CD45 expression.

WBCs count at diagnosis did not correlate with the level of CD 45 expression, this in agreement with [12-15] who report an adult ALL case with bright CD45 expression with normal leucocytic count. But in disagreement with [5]. Who found that in B-ALL cases patients who presented with TLC more than 50,000 were 9\% in CD45-low group versus $28.8 \%$ in CD45-high group, and in T-ALL cases they were $49.5 \%$ and $82.8 \%$ in low and high-CD45 groups respectively.

Regarding leukemic phenotype, there was no significant correlation with CD45 level of expression in contrast to $[5,12,16,17]$ all found that the expression of antigen was more intense in the $\mathrm{T}$ ALL cases than in B-precursor ALL cases.

DNA index ranged from 1 to 1.32 in the low group while in the high group all patients were of normal diploid number with DNA index 1 in all cases. But, no stastical significance was found between DNA index and CD45 expression. This in agreement with $[\mathbf{1 3 , 1 4 ]}$, and in disagreement with [9] who found that cases lacking the antigen were more likely to have a DNA index greater than 1.15. [5]. Found that DNA index was significantly related to CD45 expression in B-cell ALL where $22.4 \%$ of patients in CD45-low group had a DNA index $>1.16$ versus $5.3 \%$ in CD45-high group, but no significant relation was found in T-cell ALL. However, [18] reported a case of bright CD45 expression but with hyperdiploid number chromosomes.

$\mathrm{BCR} / \mathrm{ABL}$ fusion gene was found in only one case that had high CD45 expression, but there was no significant difference between CD 45-low and CD45-high groups regarding BCR/ABL fusion gene presence or absence. This in agreement with $[9,12,13]$, but in disagreement with $[5]$, as BCR/ABL fusion gene was positive in 11 cases $(4.5 \%)$ of CD45-high group. [15,18] both found negative $\mathrm{BCR} / \mathrm{ABL}$ fusion gene in spite of high CD45 intensity.

In our result $100 \%$ of patients of low CD45 expression could achieve complete remission early at day 15 of induction in contrast to the high group where only $66.7 \%$ of patient could do. This result in agreement with [5]. Who found that in Bprecursor ALL with low antigen expression 95.3\% were early treatment responders versus $89.5 \%$ in the high group. In T-ALL cases, $63.8 \%$ of the low group were good responders versus $32.4 \%$ in the high group. [8,9] also suggested an inverse relationship between quantitative CD45 expression and therapeutic outcome. But, [13] failed to find any relation between CD45 expression and treatment outcome. Also [18] reported that his case could achieve complete remission early in spite of high CD45 density.

Regarding MRD assessment at end of induction therapy, it was undetectable $(<0.01 \%)$ in $90 \%$ of the low group versus $60 \%$ of the high group, but without statistical significant difference between the two groups. In contrast to [5]. Who found highly significant difference between CD45-low and CD45 high group regarding MRD level.

Patients were stratified into low, standard and high risk groups according to risk stratification criteria in TOTAL XV protocol. In CD45-low group, $80 \%$ of patients were of Low Risk (LR) and $20 \%$ were Standard Risk (SR) while in the CD45-high group $66.7 \%$ of patients were standard risk, $20 \%$ low risk and $13.3 \%$ High Risk (HR), so there was statistical significant correlation between risk stratification and antigen expression. This came in agreement with [5]. Where patients were stratified according to NCI stratification system, among cases of BCP ALL $73.2 \%$ of patient with CD45 low expression were stratified as standard risk and $26.8 \%$ were high risk in contrast to the high CD45 expression group that consisted of $50.2 \%$ standard risk and $49.8 \%$ high risk patients. T-ALL CD45-low group consisted of $21.9 \%$ and $78.1 \%$ standard and high risk respectively while in CD45-high group there were $2.9 \%$ and $97.1 \%$ standard and high risk respectively.

Event-free survival was calculated from the date of diagnosis to last follow-up or to the first event. Patients with high CD45 expression had a worse 2-year event-free survival probability (66.7\%) compared to patients with low expression $(80 \%)$. This agrees with [5]. Who found that there was a worse 5-year event-free survival in high CD45 cases than the low (BCP-ALL: $72 \%$ in CD45-high versus 86\%in CD45-low; T-ALL: 60\% versus 78\%). Also agrees with [12] who found that in the high-risk patients, the two groups showed a striking difference in their EFS rates: The 3-year EFS rates were $88.7 \%$ in CD45-low versus $34 \%$ in CD45-high. [7] also found that there was better 
cumulative survival in patients with CD45 lower intensity.

This effect was mainly related to a higher incidence of relapse in CD45-high group (46.6\% versus $0 \%$ in the low group). This came in agreement with [5] who found that incidence of relapse had high significant relation to CD45 expression (BCPALL: $22 \%$ in CD45-high versus $11 \%$ CD45-low group, T-ALL: $31 \%$ versus $11 \%$ ) and with [15] whose case with bright CD45 developed an early relapse.

\section{References}

1- EL NAGGAR A.M., GHONAIM R.A., EL-GOHARY T.A. and ATFY M.: The prognostic value of CXCR4 and pCXXR4 in B-lineage acute lymphoblastic leukemia in adults. Egypt J. Haematol., 39: 128-33, 2014.

2- HUNGER S.P. and MULLIGHAN C.G.: Acute Lymphoblastic Leukemia in Children. N. Engl. J. Med., 373 (16): 1541-52, 2015.

3- HAGAG A.A., BADRAIA I.M., HASSAN S.M. and ABD EL-LATEEF A.E.: Prognostic Impact of WT-1 Gene Expression in Egyptian Children with Acute Lymphoblastic Leukemia. Mediterr. J. Hematol. Infect. Dis., 8 (1): e2016008, 2016.

4- MARTIN A., MORGAN E. and HIJIYA N.: Relapsed or refractory pediatric acute lymphoblastic leukemia: Current and emerging treatments. Pediatric Drugsm, 14 (6): $377-$ 87, 2012.

5- CARIO G., RHEIN P., MITLÖHNER R., ZIMMERMANN M., BANDAPALLI O.R., ROMEY R., MOERICKE A., LUDWIG W.D., RATEI R., MUCKENTHALER M.U., KULOZIK A.E., SCHRAPPE M., STANULLA M. and KARAWAJEW L.: High CD45 surface expression determines relapse risk in children with precursor B-cell and T-cell acute lymphoblastic leukemia treated according to the ALL-BFM 2000 protocol. Haematologica, JA; 99 (1): 103-10, 2014.

6- ORTOLANI C.: CD45 Antigen In: Claudio Ortolani (ed.) Flow Cytometry of Hematological Malignancies, published by John Wiley \& Sons, 1 st edition, 71-2, 2011.

7- GREDELJ-SIMEC N., JELIC-PUSKARIC' B., OSTOJIC A., SIFTAR Z., FIALA D., KARDUM-SKELIN I., VRHOVAC R. and JAKSIC'B.: Diagnostic and prognostic significance of CD45 cell surface antigen expression in hematologic malignancies with main focus on acute Leukemias. Acta Med. Croatica, 65 (1): 45-52, 2011.

8- CALDWELL C.W., PATTERSON W.P. and HAKAMI N.: CD45 expression and prognosis in acute lymphoblastic leukemia. Blood, 81 (2): 562-3, 1993.
9- BEHM F.G., RAIMONDI S.C., SCHELL M.J., LOOK A.T., RIVERA G.K. and PUI C.H.: Lack of CD45 antigen on blast cells in childhood acute lymphoblastic leukemia is associated with chromosome hyperdiploidy and other favorable prognostic features. Blood, 79: 1011-6, 1992.

10- PUI C.H., CAMPANA D., PEI D., BOWMAN W.P., SANDLUND J.T., KASTE S.C., RIBEIRO R.C., RUBNITZ J.E., RAIMONDI S.C., ONCIU M., COUSTANSMITH E., KUN L.E., JEHA S., CHENG C., HOWARD S.C. and SIMMONS V.: Treating Childhood Acute Lymphoblastic Leukemia without Cranial Irradiation. N. Engl. J. Med., 360: 2730-41, 2009.

11- LANZKOWSKY P.: Acute Lymphoblastic Leukemia. In: Lanzkowsky P. (ed.) Manual of pediatric hematology and oncology $6^{\text {th }}$ edition, ch 18. p; 367-87, 2016.

12- NAKAMURA A., TSURUSAWA M. and KATO A.: Prognostic impact of CD45 antigen expression in highrisk, childhood B-cell precursor acute lymphoblastic leukemia. Leuk Lymphoma, 42 (3): 393-8, 2001.

13- RATEI R., SPERLING C. and KARAWAJEW L.: Immunophenotype and clinical characteristics of CD45-negative and CD45-positive childhood acute lymphoblastic leukemia. Ann. Hemato., 177: 107-14, 1998.

14- BOROWITZ M.J., SHUSTER J., CARROLL A.J., NASH M., LOOK A.T., CAMITTA B., MAHONEY D., LAUER S.J. and PULLEN D.J.: Prognostic Significance of Fluorescence Intensity of Surface Marker Expression in Childhood B-Precursor Acute Lymphoblastic Leukemia. A Pediatric Oncology Group Study. Blood, 89: 3960-6, 1997.

15- SHAHAL -ZIMRA Y., ROTEM Z., CHEZAR J., ONIASHVILI N., LEADER A., RAANANI P. and RABIZADEH E.: Adult pre B-cell acute lymphoblastic leukemia with unusually large proportion of bone marrow CD45 bright/ high SSc blasts. Cytometry B. Clin. Cytom., 92 (2): 1614, 2017.

16- SAKSENA A., GAUTAM P., DESAI P., GUPTA N., DUBEY A.P. and SINGH T.: Side scatter versus CD45 flow cytometric plot can distinguish acute leukaemia subtypes. Indian J. Med. Res., 143 (1): S17-S22, 2016.

17- ZHENGYI Z., MING J., JIANHUA Q., YUJIE W. and JIANYONG L.: Clinical characteristics and immunophenotypic analysis of CD45- and CD45+ acute B lymphocytic leukemia. Chinese Journal of Hematology, 32 (11): 792-3, 2011.

18- GUPTA T., GUPTA R., MITTAL N., RAHMAN K. and NITYANAND S.: B-acute Lymphoblastic Leukemia with Bright CD45 and Moderate Side Scatter Simulating Monocytoid Population: An Unusual Phenotype. Indian J. Hematol Blood Transfus., 34 (2): 358-9, 2018. 


\section{تقييم القيمة التكهنية ل (سى دى 0 ؛ ) فى الآطفال الذين يعانون

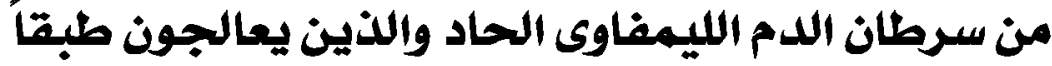

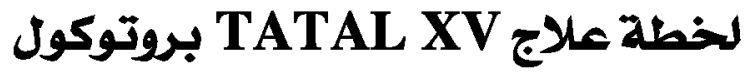

سرطان الدم الليمفاوى الحاد هو إضطراب نسخى خييث فى الخلايا الآولية لنخاع العظم الليمفاوى مع تراكم الخلايا الليمفاوية الخبيثة

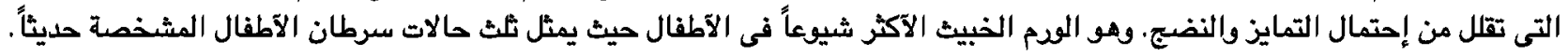

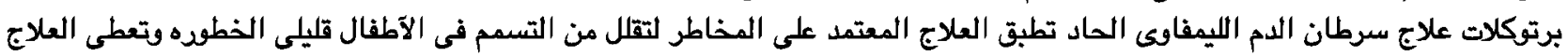

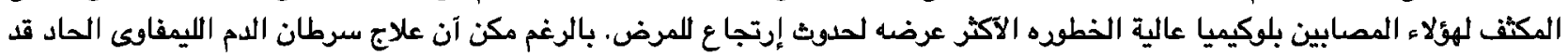

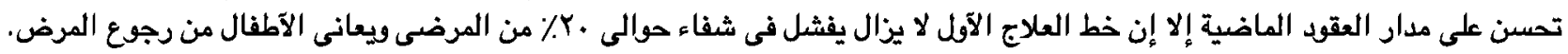

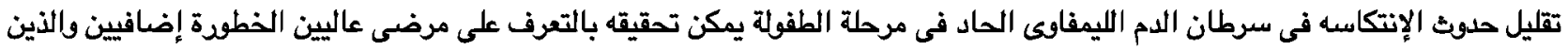

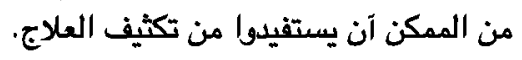

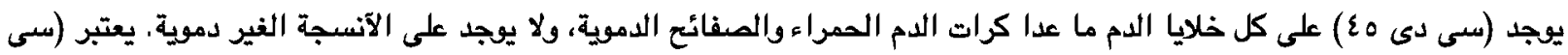

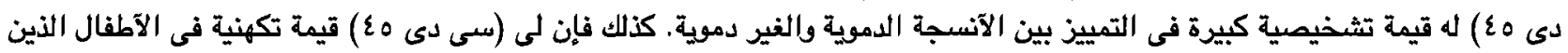

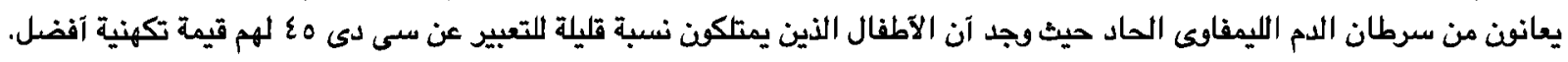

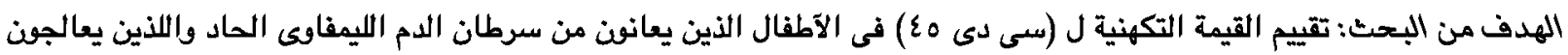

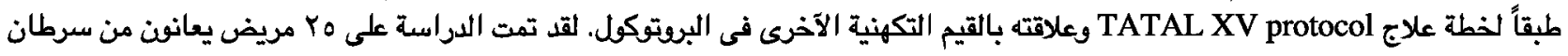

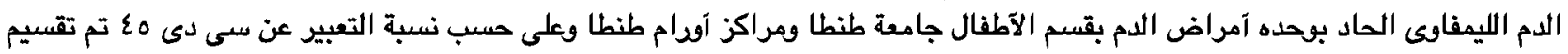
المرضى إلى مجموعة عالية التعبير وآخرى منخفضة التعبير.

$$
\begin{aligned}
& \text { لقد خضع المرضى للآتى: } \\
& \text { ا- آخذ التاريخ المرضى كاملاً. } \\
& \text { Y- نحص إكلينيكى شامل. }
\end{aligned}
$$

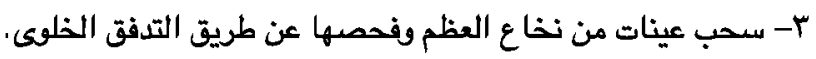

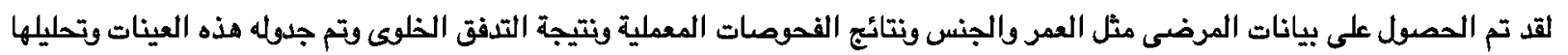

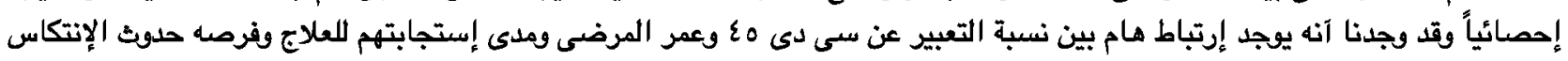

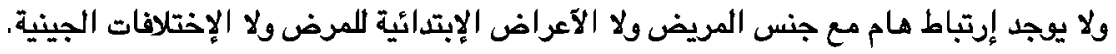

